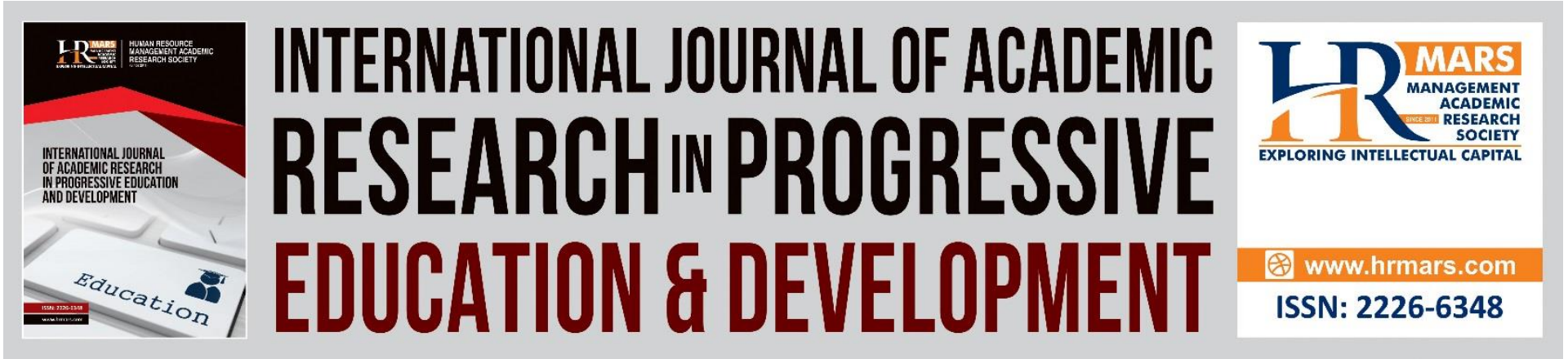

\title{
Critical Success Factors of Authentic Learning Teacher Competency: Teachers' Perception
}

\section{Vijaya Letchumy Baskaran \& Norazilawati Abdullah}

To Link this Article: http://dx.doi.org/10.6007/IJARPED/v10-i3/10713

DOI:10.6007/IJARPED/v10-i3/10713

Received: 08 June 2021, Revised: 14 July 2021, Accepted: 23 July 2021

Published Online: 07 August 2021

In-Text Citation: (Baskaran \& Abdullah, 2021)

To Cite this Article: Baskaran, V. L., \& Abdullah, N. (2021). Critical Success Factors of Authentic Learning Teacher Competency: Teachers' Perception. International Journal of Academic Research in Progressive Education and Development, 10(3), 61-81.

Copyright: (C) 2021 The Author(s)

Published by Human Resource Management Academic Research Society (www.hrmars.com)

This article is published under the Creative Commons Attribution (CC BY 4.0) license. Anyone may reproduce, distribute, translate and create derivative works of this article (for both commercial and non-commercial purposes), subject to full attribution to the original publication and authors. The full terms of this license may be seen

at: http://creativecommons.org/licences/by/4.0/legalcode

\section{Vol. 10(3) 2021, Pg. 61 - 81}

Full Terms \& Conditions of access and use can be found at http://hrmars.com/index.php/pages/detail/publication-ethics 


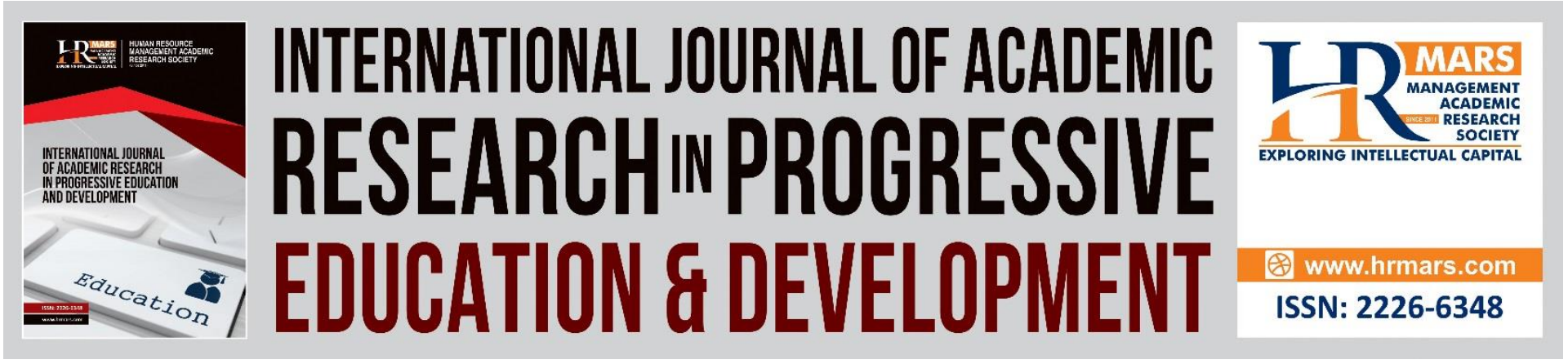

\title{
Critical Success Factors of Authentic Learning Teacher Competency: Teachers' Perception
}

\author{
Vijaya Letchumy Baskaran \& Norazilawati Abdullah \\ Faculty of Human Development, Sultan Idris Education University, National Child \\ Development Research Centre, Sultan Idris Education University
}

\begin{abstract}
This paper discusses critical success factors involved in developing Authentic Learning Teacher Competency Model based on Malaysian education system. Authentic learning is an approach that facilitates learners' acquisition of knowledge by exposing them to real-world experiences. Implementing authentic learning approach requires educators to carry out a learning design that connect what learners are taught in school to real-world issues, problems and applications. Learning taught through this way must be able to mirror the complexities and ambiguities of real-life. Therefore, a semi-structured interview was conducted to identify the critical success factors required by educators to be competent in implementing authentic learning approach. This paper represents educators' perception in achieving competency implementing authentic learning approach. Educators are required to prepare the learners for the unknown future by fostering 21st century skills during the teaching and learning activities through authentic learning approach. The findings of the study demonstrate that educators agreed that knowledge, skill and attitude competency are the relevant themes involved in developing the Authentic Learning Teacher Competency Model.
\end{abstract}

Keywords: Authentic Learning, Teacher Competency, Knowledge, Skill, Attitude

\section{Introduction}

Malaysia is now working hard towards transforming its education system to be at par with other developed countries. It is striving to produce learners who will able to perform in the global landscape. Thus, for it to become a reality, improving the quality of educators are vital to improve the quality of the education system. Educators being the main implementers of education, have a big responsibility to achieve that goal. This task is becoming more and more daunting due to the workloads and excessive expectations of the community towards educators. Constant changes that are occurring in the curriculum, requires educators to adapt quickly. Therefore, it creates a situation where educators not being able to perform and seen less competent.

The education system is said to be transformed when the learners are able to adopt the role of professionals and stimulate real-life situations that will enhance transferability of knowledge. A situation that can happen if educators apply authentic learning approach during 
their teaching and learning activities. According to Behizadeh \& Fink, (2015) authenticity occurs when learners' perception of the tasks given connected to their daily lives. Authentic learning has evolved through constructivist learning, disciplined inquiry, higher order thinking and problem- solving approach (Latham \& Carr, 2012).

According to Herrington et al (2010), when there is more teaching and learning activities that could relate the students with the real-life situations around them, the more enhanced their knowledge and skills would be and more meaningful will their learning would be. Pearce (2016) have supported this statement also by implementing that educators have also agreed to the fact which learning is optimal when it is carried out through experiences by doing rather than just listening and observation.

Lim (2012); Zachariah (2013); Jefferson (2009), have stated that competent educators will be able to change the scenario of the Malaysian education system. But unfortunately, the preparedness of teaching profession is getting more complicated and irrelevant. As it is stated in the 7th shift (MEBP, 2013-2025) that even though we have many excellent educators but only $50 \%$ lessons are being delivered in an effective manner.

Competent educators are able to produce learners who are able to think critically, creatively and able to develop 21st century learning skills among the learners and connect learning in the classroom to the real world. Teaching and learning in the classroom should be carried out in way that the education system must conform to the learners rather than learners conform to the system. Implementing authentic learning approach gives an opportunity for learners to attain all three goals of learning: acquisition of skills, understanding of concepts and knowledge application (Wornyo, 2018).

Competencies are directly correlated to the educators' responsibilities and capabilities. Educators require a wide range of competencies in order to face the complex challenges of today's world. Authentic Learning Teacher Competency Model will make it easier for these modern educators to understand the Authentic Learning Instructional Design to foster 21st century learning skills among our learners.

Therefore, this study is focused on educators in the Manjung district. Even when there are abundance of theory and positive feedback from implementing authentic learning approach in daily teaching and learning activities, there still many more aspect of this approach that are new to us. The question here is, how do our educators perceive the authentic learning teacher competency model in their daily teaching and learning practices and what are the main constructs that are involved in that competency model?

\section{Problem Statement}

The global workforce of the future must be qualified with high competitiveness and employability skills. But unfortunately, many employers are claiming of lack of expertise among job seekers. Insufficient skills among these job seekers are related to the issue of education quality. Research carried out by Tan, Teo, and Chye,2009; Ramakrishnan and Yasin, 2012 had indicated that graduates now are seen lacking in crucial skills needed by the industry such as creative and critical thinking skills, communication skills and problem-solving skills. 
DEVELOPMENT

Vol. 10, No. 3, 2021, E-ISSN: 2226-6348 @ 2021 HRMARS

The Central Bank of Malaysia (2019) had reported that the rate of unemployment among Malaysian graduates are seriously at a worrying state. Malaysian graduates are seen to be lacking of job experience and having insufficient skills or knowledge for them to compete in the labour market. Technical skills, problem solving skills and communications are seen not mastered by these graduates. Problems arrive when graduates are not able to implement what they have learned in their working field. For us to meet the needs and expectations of the $21^{\text {st }}$ Century learners, schools will need to work hard to adopt a $21^{\text {st }}$ century skills curriculum and redesign the methods of instruction that will incorporate innovative, research proven teaching strategies, modern learning technologies and real-world resources and contexts.

According to Hanapi and Nordin (2014) also, the quality of education acts as the main factor to the unemployment problem among graduates. This is because the failure of ensuring educational syllabus or curriculum consistent with the matters required in the job market. The curriculum and components of educational field are not in line with the required workplace skills that leads to the difficulties among the graduates to obtain jobs which match their skills and qualifications. It is common to see scenarios where learners are visibly disengaged from what they are learning. This is due to the fact that our understanding towards implementation of Authentic Learning is still shallow.

Authentic learning approach is seen to facilitate understanding thus meaning is constructed. Educators must redefine their conceptions and redesign the instructional strategies that allow learners to meet the needs of $21^{\text {st }}$ Century education. The knowledge and competency needed by our educators must be able to change the structure and format of the current schooling systems, one that is still implementing the skills of repetition, basic applied knowledge and limited literacy to a modernized education system of the $21^{\text {st }}$ century. (Kereluik et al., 2013).

The professional competencies of the $21^{\text {st }}$ Century educator requires an educator to not only be a provider of the knowledge and skills but also create meaningful opportunities for learners' mastery of $21^{\text {st }}$ Century skills. Greenhill (2010) A competent educator will have to ensure learners to feel and have real-world opportunities to synthesize, apply and demonstrate their mastery of key concepts and $21^{\text {st }}$ Century skills.

Researches carried out in Malaysia have identified that Authentic Learning has a positive impact on developing students' creative and critical thinking skills. Tan et al (2014). By implementing Authentic Learning environment, learning is seen successfully developing the learners' creativity. Collaborating while learning has become a contributing factor to the learners to develop career transcending skills since learners were able to use higher-order thinking skills and acknowledged the fact that this learning environment is real and relevant to their learning process.

Here in Malaysia. the disciplinary approach of applying authentic learning to enhance the learners' individuality and creativity in different learning situations and later instilling 21st century skills is still vague among the educators. Therefore, it is important to develop this competency model to provide a clearer view on implementing authentic learning, the 
educators' perception towards the main construct needed in developing the competency model must be identified from the educators themselves.

\section{Purpose of the Study}

The essence of conducting authentic learning among our students is to enable the learner's voice to be heard. Learners must learn to adopt the role of professionals, simulating real life situations to enhance transferability of knowledge. This approach enables the learners to think critically, develop 21st century learning skills and connect learning in the classroom with the real world.

This study is carried out to identify the critical success factors needed in developing Authentic Learning Teacher Competency Model. This competency model is developed to expose educators to authentic learning approach to 21st century learning skills among the learners for them to perform in the future workforce. Educators have a responsibility of preparing learners for the work and situation that have not been created yet.

\section{Research Objectives}

This research is carried out to identify critical success factors that are involved developing a Teacher Competency model. Hence the objectives of this research is:

a. To identify the constructs affecting Teacher Competences in implementing Authentic Learning.

\section{Research Questions}

Based on the objectives of this study, these are the research questions that will be answered by the end of this study.

a. What are the constructs affecting Teacher Competences in implementing Authentic Learning approach?

\section{Literature Review}

The world is evolving rapidly from a traditional, industrial base dependent on factories and physical labour to a new paradigm where $21^{\text {st }}$ Century Skills are at the centre stage in the coming of new age. Wagner (2008); Winner, Goldstein \& Vincent-Lancrin (2013); Drucker (1995); Scardamalia (2000); Bereiter (2002); Gardner (2008); Pink (2005); Canadian Council of Learning (2010), Partnership for $21^{\text {st }}$ Century Skills (2007). Therefore, it has been more than two decades now that, $21^{\text {st }}$ century skills have been emphasized by researchers, educators, policymakers and stakeholders.

Learners are required to master the knowledge that is rapidly expanding together with technologies and work process which are also evolving. They have to possess the ability to think critically and solving problems by analysing, synthesizing and applying knowledge learnt to novel situation. They must be able to manage complex projects competently by finding resources and tools that are needed (Darling-Hammond et al., 2019).

Educators now must be able to prepare the learners to face these transformations and pave the way for our learners to face these upcoming challenges. In a study that was carried out by The National Research Council's (NRC) review (Pellegrino, Hilton, \& National Research 
Council, 2012), scholars have dictated a different kind of teaching and learning approach must be carried out by educators for their learners develop these kinds of skills and abilities. The kind of approach that supports higher order thinking developed by applying knowledge to new situations and collaborative problem-solving. It is the authentic learning approach. An approach where learners can learn independently, with curiosity, inventiveness and creativity.

When learning occurs authentically, it is self-directed, self-regulated, independent and autonomous. The impact of learning authentically will be able to make learners focus on creating knowledge by implementing skills such as analytical thinking, problem solving by carrying out meta cognitive activities Niemi (2002); Lavonen (2008); Rotgans \& Schmidt (2011); Niemi \& Nevgi (2014).

Knowledge delivered passively will not help learners to be equipped with skills that are needed in the future, which will later be the cause of a significant economic and social consequences. How are we going to change these scenarios to produce learners who are ready for the upcoming future?

Thus, in this research, the competency of educators implementing authentic learning approach has been given emphasize. Authentic learning is known as an instructional strategy that "focuses on real-world, complex problems and their solutions, using problem-based activities, case studies and participation in virtual communities of practice" Lombardi (2007), as it is also supported by Herrington et al (2014) that a pedagogy that is authentic allows learners to be engaged in completing realistic tasks or assignments by using real-world resources and tools. The learners will be able to pretend to be the professionals as they are solving those issues. This research not only discusses on the approach of authentic learning but also the competency needed by the educators to apply and execute the strategies in their respective classrooms.

An educator's competencies may be defined in terms the educator's knowledge, skills and attitudes or behaviour. Competencies needed by an educator can only be understood clearly if we understand the job of an educator. According to Darling-Hammond (2006), an educator's task is to prepare learners with higher order thinking and performance in order to allow them to perform well in the future. In short, an educator must be able to prepare the learners for the unknown.

Competent educators will be able to implement the curriculum successfully. Education is the process of delivering knowledge and skills that will be descended from one generation to the other. Hence, quality educators will become the main factor in determining the achievement of the learners at school. High quality educators must be competent and committed in driving the learners towards their excellence.

An educator that is assumed competent must have mastered more than just knowledge and skills. Educators need a wide range of competencies in order to face the complex challenges of today's world. The principal aim of this study is to identify the constructs that influences the competencies of a modern teacher who understands the 
DEVELOPMENT

Vol. 10, No. 3, 2021, E-ISSN: 2226-6348 ㄷ 2021 HRMARS

Authentic Learning Instructional Design which will be used to foster the 21st century learning skills among our learners. Hence in this study, the teacher competence has been identified by several models and ideas through focusing on the elements of teachers' knowledge, skills and attitude.

\section{Research Methodology}

Semi structured interviews, has been chosen as a method of research in this research because it helps in obtaining information regarding a process of phenomenon studied (Wahab \& Shah, 1992; Locke, 1976; Ryan, 1982; Sekaran, 2000).

The number of samples involved in this study is nine as suggested by Haplin (1957), which supports the idea that a small number of samples is adequate as interview respondents. In this interview, the selection of sample involves nine respondents that were selected as a focus group member using a targeted sampling strategy (purposive sampling). The nine respondents are four SISC+ officers (every field of subject) from the District Education Department of Manjung, and 2 educators from Secondary schools, 1 each from National type school, Chinese Vernacular school and Tamil vernacular school.

According to Chua (2011), the method of interviewing gives an advantage to researchers to gain a more in-depth response and views. According to him also, the semistructured interview method occurs where semi-formal interview sessions were planned, designed and implemented according to a list of questions that could be arranged during the interview session. This method is used to create a comfortable and non-formal atmosphere between the interviewer and the respondent during the session.

During this interview, the content, including the questionnaire and its procedures were pre-planned. Thus, this interview is guided and controlled by the interviewer according to the planned framework which will later assist in data analysing.

The semi structured interview will be carried out by using the same format and same questions towards each respondent, this will help in increasing the reliability of the interview conducted. Silverman 1993 in Cohen et. al. 2000.

The researcher had used audio recorders to record conversations that are being conducted to ensure that no information is left out. Quotations of conversations or conversations from interview transcripts were used to support the interpretation and conclusions of the writing. The researcher had used a table to describe the overall data of the interview conducted.

This study has implementing thematic coding techniques - deductive coding (thematic) analysis coding techniques (deductive coding analysis) to identify the relevant themes involved in developing the authentic Learning Teacher Competency Model. 
INTERNATIONAL JOURNAL OF ACADEMIC RESEARCH IN PROGRESSIVE EDUCATION AND

DEVELOPMENT

Vol. 10, No. 3, 2021, E-ISSN: 2226-6348 @ 2021 HRMARS

\section{Research Findings}

Table 1. Summarizes the background of the interview respondents.

\begin{tabular}{|l|l|l|l|l|}
\hline Background & Gender & Age & Race & Position \\
\hline Respondent 1 & Male & 52 years old & Malay & PPD Officer \\
\hline Respondent 2 & Female & 46 years old & Malay & PPD Officer \\
\hline Respondent 3 & Male & 43 years old & Malay & PPD Officer \\
\hline Respondent 4 & Female & 54 years old & Malay & PPD Officer \\
\hline Respondent 5 & Male & 54 years old & Indian & Secondary School \\
\hline Respondent 6 & Female & 45 years old & Indian & Secondary School \\
\hline Respondent 7 & Female & 53 years old & Indian & Tamil Vernacular School \\
\hline Respondent 8 & Female & 48 years old & Indian & National Primary School \\
\hline Respondent 9 & Female & 35 years old & Chinese & Chinese Vernacular School \\
\hline
\end{tabular}

After the initial session of introducing the interviewee and the interviewer, the next question was asked no longer according to the protocol of the interview itself but rather based on the response of the respondents. Questions will be rephrased according to the response received from the respondents.

By carrying out the interview through this way will help in providing a holistic view of teachers' perception regarding the competency needed in conducting authentic learning approach in classrooms. The interview questions are closely linked to each other and sometimes repeated. The transcripts and interview notes have been carefully researched to identify a number of conclusions that will result in category analysis.

The interview questions are based on two themes, (1) respondents' understanding on teacher competency (2) respondents' perception on authentic learning.

\section{i. Teacher Competency}

Curriculum planning and implementation requires educators who are competent to produce learners who can solve complex life problem (Rahman \& Mahamood, 2017). High level of teaching quality is vital in raising student achievement, which it requires high degree of teacher competency. Hasnah (2017) and it is also supported by Haizumah (2019) that explained, an educator's quality depends on their competency determining the learning success and facilitation.

Competent educators are able to simplify the teaching and learning activities by conducting systematic teaching and learning session, appropriate content knowledge delivery starting from the engagement of the learners to the development of the knowledge and skills needed by the learners. Siraj (2012), have stated a competent educator will be able to work collaboratively with other educators in educating learners based on their interests. They are innovative in solving problems creatively and carry out their responsibilities with integrity and respect. Through the interview, these are the responses received from the respondents. (Refer to Appendix).

It can be concluded that respondents have agreed that a teacher competency standard consists of knowledge, skills and attitude. An educator that has higher level of competency is 
able to produce learners who can think creatively and critically thus enabling them to perform in their future undertakings. A competent educator is responsible in preparing his or her students with higher order thinking and performance skills. A competent educator has a transformative power towards their learners. Their ability in making the school an exciting and interesting place is will not go unnoticed. A competent educator is seen able to inspire learners to be familiar with creative and critical thinking skills, to think deeply about any given subject and take on more challenging work for them to face their lifelong educational and career aspirations.

Respondents have agreed that an educator is considered to be competent when they have the verbal ability, content knowledge, pedagogical knowledge and skillful teaching strategies to cater the needs of every student. Their ability of maximizing instructional time via effective classroom management and organization and later enhancing instructional strategies, activities and also assignments to ensure learners' achievement will not go unnoticed.

Thus, competency can be concluded as knowledge, skills and abilities combined in order to perform any job successfully. Competency of a teacher can be conceptualized as combination of personal characteristics and attitudes, knowledge, skills and attitudes that are required by educators to perform effectively in various teaching contexts.

\section{ii. Authentic Learning}

Herrington et al (2014) and Lombardi 2007 have said that an instructional strategy is said to be authentic when the activities carried out are focusing on real world, complex problems and their solutions that are relevant to the students' life. The pedagogy must be able to allow learners to be engaged in completing realistic tasks or assignments by using real-world resources and tools. Learners will be able to pretend to be the professionals as they are solving those issues. Meanwhile Har (2016) had defined authentic learning as learning by participating and working on real-world problems.

The goal of authentic learning can be achieved if educators are able to link knowledge with real world experiences, which at the end would be an important component in the $21^{\text {st }}$ century teaching model. Herrington \& Kervin (2007) agrees that when educators are able to link content with reality, learners are able to engage in the learning environment effectively to promote future skills such as critical thinking, problem solving, problem solving and collaborative learning. The respondents' response regarding authentic learning is as follows. (Refer to Appendix).

The interview carried out among these 9 respondents have suggested that authentic learning is still a new concept for them. Many had responded by saying that authentic learning is somewhat similar to contextual or constructivism learning type where learning is carried out meaningfully. This is when learning happens by exposing students to real life situations and complex problems that might arise in the future. Learning would occur by relating content to their daily life experiences.

Authentic learning is deemed quite difficult to be carried out by the respondents. This is due to the fact that these respondents are still attached to the old paradigm of teaching 
where knowledge is transmitted to answer examinations at the end of the course. Many have expressed their concerns that if they were to carry out authentic learning approach, time constraint is the main issue that they have to face. Not only that, the school administrators also have to play a big part in allowing collaboration of professional experts with the school to allow authentic learning approach to be carried out effectively.

Authentic learning approach happens when learners collaborate with educators and other students. This will allow them to explore any information given based on their judgements and values. Learning would be student centred and knowledge gained during this process is constructed by the learners themselves. According to the respondents, this way of learning requires a lot of time to prepare, therefore authentic learning approach is deemed difficult to be carried out. This is because, educators are used to use a common approach of presenting tasks and problems to simplify the topic by breaking it down into its component parts.

Nonetheless, the respondents do agree that authentic learning approach motivates the learners because they can be seen highly engaged in completing those tasks and perform with enthusiasm and care during the learning process because they attribute value to it. The task at hand will become meaningful and valuable for them. Respondents also agreed that authentic learning approach will equip the learners with the tools that they need to meet the demands of the future. To be future ready, learners must equip themselves with problem solving and critical thinking skills that are vital for the future. Collectively, the respondents have agreed that a competency model on authentic learning approach is necessary to act as a guideline for teachers to conduct authentic learning approach at schools.

\section{Discussions}

Findings from the interview can be divided into two main components. The first one would be on the teachers' understanding on competency of an educator. The second component would be the perception of teachers in implementing the authentic learning approach in their daily teaching and learning activities.

From the first part of the interview, it can be concluded that many teachers have stated that a competency of an educator is seen in the way the lesson is delivered. An educator is considered to be a specialist in what they are doing when they are competent. The ability of educators to use their knowledge and skill to improve their practice and finding ways to meet new teaching demands greatly resonates with teacher competency. These educators have also agreed that vast pedagogical content knowledge, having problem solving skills and continuously adapting according to diverse learners' needs, ever ready in making the best decision needed in the classroom are just some of the elements needed to become a competent educator. Competency in attitude also plays a big part here, where a competent educator has greater sensitivity to context and greater respect for students by being kind and caring. It can be concluded in the first part of the interview that teacher competency involves in more than just knowledge, skills and attitudes also contribute to the teacher professionalism. 
The second component of the interview reflects on the knowledge and perception of educators in conducting authentic learning approach at schools. From the interview, it is clear that the concept is still new. But there are feedbacks from the educators that have agreed that authentic learning approach is mainly derived from constructivism theory, where learners are seen learning actively and continuously to incorporate knowledge that are gained from experiential and practical experiences in the classroom.

Many educators also have confessed that most of the time the lesson is being conducted through teacher centered method and focused mostly towards completing the syllabus because they do not have the basic guidelines in conducting authentic learning during their lessons. Authentic learning is generally learning by doing and so it requires educators prepare lessons that has ill-defined problems or activities that has real-world relevance. They have confessed that in order to do that it requires ample of time and permission from the administration. Lack of knowledge in conducting authentic learning have caused these learners to shy away from conducting it. The closest that they could relate to deliver meaning is by giving examples of their daily lives.

Conducting a pedagogy that integrates multiple subjects at one time is not a common practice among these educators. A modular approach is rarely seen in their lessons. Most of them are only concentrating on their own subject because it requires in depth planning before carrying it out. For educators to bring in the experts with skills of the real world is quite difficult since it involves many parties to agree to that. The standard of operations that must be followed each time they invite these experts causes a huge burden on educators. Time constraint is also a serious issue faced by the educators since they are rushing to finish the syllabus.

Respondents agreed that if teaching is still focused on finishing the syllabus, then it would be difficult for the learners to apply the knowledge learnt in their real lives. This is because they are mostly required to regurgitate the knowledge that they learn during the examinations. Educators are seen having difficulties to design a learning strategy that can help learners to explore issues from different perspectives because it takes a lot of time and preparation. The best that they could do is through group work, where students are given chance to give their opinion on the any situation given.

Collaboration in the teaching and learning sessions in the classroom is usually seen during teaching and learning sessions in the classrooms, where mostly the smarter ones will help the weaker ones. Learners are required to collaborate to finish the assignments given. Mostly learners are still seen dependent on the educators to finish it because the given task does not allow the students to use their autonomy to finish the task.

According to the educators, assessment is an ongoing process in their classroom, since Classroom Assessment (PBD) is being carried out. Even though it is carried out holistically and not by looking at the grade, they are mainly carried out individually and not in groups. Learners are usually expected to have an end product of any project given and the effort put to finish the product is often ignored. 
From the interview, learners have said that they are able to provide support for their learners to have the confidence by asking higher order thinking skills questions. Questioning using the higher order thinking skills will allow them to elicit the learners' knowledge and educators can check on their prior knowledge of any particular lesson. It is obvious that most of the educators believe in order for learners to master $21^{\text {st }}$ century learning skills, conducting authentic learning approach is one of the best ways to do it. Authentic learning is helpful in fostering $21^{\text {st }}$ century skills because the elements of that approach will help them to relate to their daily lives.

Educators have identified several critical success factors that are needed to conduct authentic learning approach in schools. The factors are that they need to have a deep knowledge on many components such as knowledge of learners, knowledge of curriculum, knowledge of context, knowledge of subject matter and knowledge of assessment to conduct authentic learning. Adaptability skills and the right attitude towards the approach is also important. They have to be resilient to changes and willing to share the responsibility of learning with their learners. Thus, they need a teacher competency model to act as a guide for educators to conduct authentic learning approach at schools.

\section{Conclusion}

The world now seen evolving rapidly from a traditional, industrial base dependent on factories and physical labour to a new paradigm where 21st Century Skills are becoming the most needed elements in the coming of new age. (Wagner,2008; Winner, Goldstein\& VincentLancrin, 2013; Drucker,1995: Scardamalia,2000, Bereiter,2002, Gardner,2008, Pink, 2005: Canadian Council of Learning,2010, Partnership for 21st Century Skills,2007). Unfortunately, knowledge that are currently delivered passively will not allow our students to be equipped with those $21^{\text {st }}$ skills needed in the future, thus later be the cause of a significant economic and social consequences. We need teachers to change these scenarios to produce students that are functional in the future.

In this study, authentic learning approach had been given centre stage in the process of creating students who are future ready. A learning process that occurs authentically is selfdirected, self-regulated, independent and autonomous. This situation will créate a situation that allow learners that can be an expert of that knowledge that is always evolving together with technologies and work process (Niemi, 2002; Lavonen, 2008; Rotgans \& Schmidt, 2011; Niemi \& Nevgi, 2014).

Therefore, educators must be able to use a teaching method that allows empowerment that has sense of freedom in learning because it will make learning more meaningful. Authentic learning is an instructional approach that emphasizes on attention given to knowledge and information that is relevant to the learners. Learners would be challenged to address and handle tasks and explore content relevant to their daily life to improve their academic achievement and problem-solving skills.

It can be concluded from this study that educators had identified the critical success factors needed by them to become a competent educator conducting Authentic Learning approach. They have agreed that Authentic Learning Teacher Competency Model that is 
structured ideally and skilfully can help in prompting educators' performance in their teaching and learning activity. This semi structured interview also had given meaningful insights on structuring a competency model by taking account into three main integrated elements such as knowledge, skills and attitudes.

\section{Acknowledgement}

I would like to express my gratitude to my supervisor, Assoc. Prof. Dr. Norazilawati Abdullah, who guided me throughout this study. I would also like to thank my friends and family who supported me. I also wish to acknowledge the help provided by the District Education Department of Manjung. My deep appreciation for the education officers who have helped by participating in the interview conducted and offered deep insight into the study

\section{Corresponding Author}

Assoc. Prof. Dr. Norazilawati Abdullah

Deputy Director National Child Development Research Centre (NCDRC) Universiti Pendidikan Sultan Idris Sultan Azlan Shah Campus, Proton City, 35900 Tanjung Malim, Perak.

Email: nora@fpm.upsi.edu.my

\section{References}

Behizadeh, N., \& Fink, L. S. (2015). Engaging students through authentic and effective literacy instruction. Voices from the Middle, 23(1), 40-50.

Canadian Council of Learning (2010). Taking Stock of Lifelong Learning in Canada (2005- 2010): Progress or Complacency? Retrieved from ww.ccl-cca.ca Central Bank of Malaysia (2019)

Chua, Y. P. (2012). Kaedah dan statistik penyelidikan: Asas statistik penyelidikan Buku 2. (2nd Edition) Kuala Lumpur: McGraw Hill (Malaysia)

Cohen, L., Manion, L., \& Morrison, K. (2007). Research Methods in Education. 6th Ed. London: Routledge.

Duncan, R. G., Rogat, A., \& Yarden, A. (2009). A learning progression for deepening students' understandings of modern genetics across the 5th-10th grades. Journal of Research in Science Teaching.

Desimone, Laura. (2009). Improving Impact Studies of Teachers' Professional Development: Toward Better Conceptualizations and Measures. Educational Researcher. 38. 181-199. 10.3102/0013189X08331140.

Gardner, H. (2008). 5 Minds for the Future. Boston: Harvard Business School Press

Greenhill, Brian. (2010). The Company You Keep: International Socialization and the Diffusion of Human Rights Norms. International Studies Quarterly. 54.127 - 145. 10.1111/j.1468-2478.2009.00580

Hanapi, Z., \& Nordin, M. S. (2014). Unemployment Among Malaysia Graduates: Graduates' attributes, Lecturers' Competency and Quality Of Education. Social and Behavioral Sciences 112, 1056-1063.

Herrington, J., \& Kervin, L. (2007). Authentic learning supported by technology: 10 suggestions and cases of integration in classrooms. Educational Media International, 44(3), 219236.

Herrington, J., Reeves, T. C., \& Oliver, R. (2010). A Guide to Authentic e-Learning. London and New York: Routledge. 
Herrington, J., Reeves, T. C., \& Oliver, R. (2014). Authentic Learning Environments. New York: Springer.

Jamil, H., Razak, A., Raju, R., \& Mohamed, A. R. (2011). "Teacher professional development in Malaysia: Issues and challenges." In Africa-Asia University Dialogue for Educational Development Report of the International Experience Sharing Seminar: Actual Status and Issues of Teacher Professional Development (p.85-102). CICE Series 5. Hiroshima: Hiroshima University. Yoon.

Latham, G., \& Carr, N. (2012b). Building on authentic Learning for Pre-Service Teachers in a Technology-Rich Environment. Journal of Learning Design, 5(1), 32-42

Lombardi, M. M. (2007). Authentic learning for the 21st century: An overview. Educause Learning Initiative Paper, 1(2007). http://alicechristie.org/classes/530/EduCause.pdf. Accessed 20 Dec 2014

Ministry of Education Malaysia. (2013). Malaysia Education Blueprint 2013-2025.

Partnership for 21st Century Skills. (2007). Beyond the Three Rs: Voter Attitudes Toward 21st Century Skills. Tucson, AZ: Author

Pink, D. (2005). A Whole New Mind: Moving from the Information Age to the Conceptual Age. New York: Riverhead Books.

Ramakrishnan, K., \& Yasin, N. M. (2012). Knowledge management system and higher education institutions. International Conference on Information and Network Technology (IPCSIT) 37, 67-71.

Saedah, S., \& Sani, M. I. (2012). Standard Kompetensi Guru Malaysia. Prosiding Seminar Kebangsaan Majlis Dekan Pendidikan Malaysia.

Scardamalia, M. (2000). Social and Technological Innovations for a Knowledge Society. In S. SC. Young, J. Greer, H. Maurer, \& Y.S. Chee (Eds.). Proceedings of the ICCE/ICCAI 2000: Volume 1. Learning Societies in the New Millennium: Creativity, Caring Commitments. (pp. 22-27). National Tsing Hua University, Taiwan: Taipei. Online: https://portal.utoronto.ca/bbcswebdav/xid-1113975_1.

Sekaran, U. (2000), Research method for business: A skill building approach, John Wiley and Sons, Inc.

Tan, O. S., Chye, S., and Teo, C. T. 2009. Problem-based Learning and Creativity: A Review of the Literature. IN Tan, O. S. (ED.). Problem-Based Learning and Creativity Singapore: Cengage Learning Asia Pte Ltd. 15-38.

Wagner, Tony. (2008). The Global Achievement Gap: Why Even Our Best Schools Don't Teach the New Survival Skills Our Children Need-and What We Can Do About It. New York: Basic Books

Winner, E., \& Goldstein, T. R. Vincent-Lancrin, S. (2013). Art for art's sake? The Impacts Of Arts Education. Paris, France: OECD Publishing 


\section{Appendix}

Through the interview, these are the responses received from the respondents.

\begin{tabular}{|c|c|}
\hline 10 & \\
\hline A & 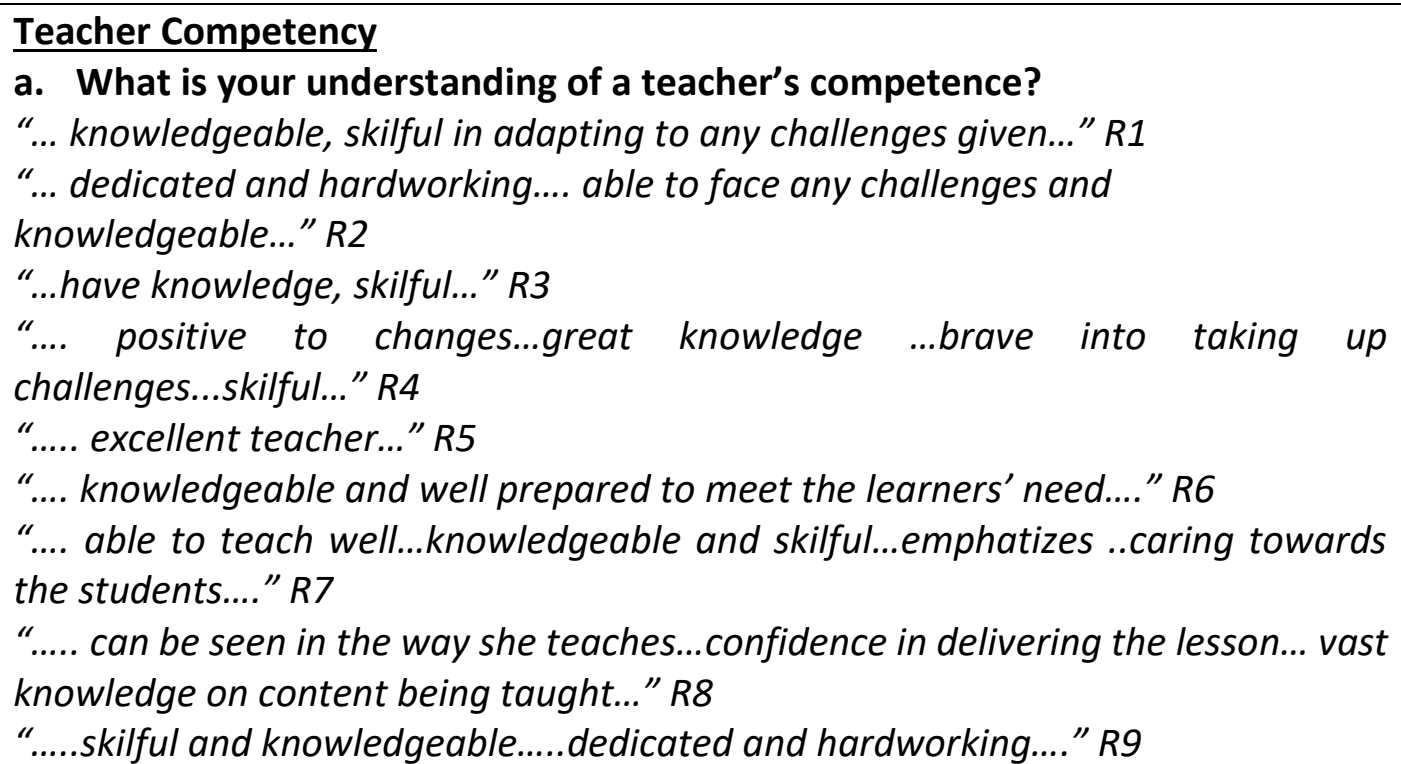 \\
\hline & $\begin{array}{l}\text { b. How are we able to identify competent educators? } \\
\text { "... a teacher who is well-versed...skilful and knowledgeable .." } R 1 \\
\text { "...able to adapt with new policies..." R2 } \\
\text { "... knowledgeable, skilful and dedicated..." R3 } \\
\text { "...vast knowledge in subject matter...pedagogical knowledge .... skilful in any } \\
\text { field..." R4 } \\
\text { ".... hardworking...knowledgeable... skilful ... highly adaptable..." R5 } \\
\text { "...able to apply suitable teaching and learning styles according to the students" } \\
\text { life...." R6 } \\
\text { "...able to tackle any given problem...able to handle and guide the weaker students } \\
\text { in any way possible..." R7 } \\
\text { " great knowledge... highly skilled...in any given task and also deep empathy } \\
\text { towards the students that are being taught..." R8 } \\
\text { "... able to take up any challenges... adapt to any new situations..." R9 }\end{array}$ \\
\hline$B$ & $\begin{array}{l}\text { Authentic Learning } \\
\text { c. What is your understanding in teaching using the Authentic Learning } \\
\text { approach? } \\
\text { "...an approach that uses examples from the students' daily lives...similar to } \\
\text { contextual learning..." } 11 \\
\text { "...an approach that uses real activities ..... integrating } 21^{\text {st }} \text { century skills. ." } R 2 \\
\text { "...involves higher order thinking skills..... constructivism.... involving the students' } \\
\text { life..." R3 } \\
\text { "...involving the students' experience...teaching and learning activities that is } \\
\text { orientated to things that are familiar to the students... building new concepts from } \\
\text { their prior knowledge...similar to conceptual knowledge..." R4 } \\
\text { "... learning that happens when it is connected to their daily life..." R5 }\end{array}$ \\
\hline
\end{tabular}




\begin{tabular}{|c|}
\hline $\begin{array}{l}\text { "... learning that has relevancy towards the learners' life...an approach that fills } \\
\text { the gap of what is learned at school with the outside world...." R6 } \\
\text { ".... teaching is carried out authentically... real-life examples are used in the } \\
\text { classrooms.... relevancy of the topic taught to the learners' real life..." } R 7 \\
\text { "...an approach that allow learners relate their daily life in their learning...instill } \\
21^{\text {st }} \text { skills among the learners..." R8 } \\
\text { "... an approach that helps learners to master } 21^{\text {st }} \text { century skills...contextual } \\
\text { learning...meaningful learning..." R9 }\end{array}$ \\
\hline 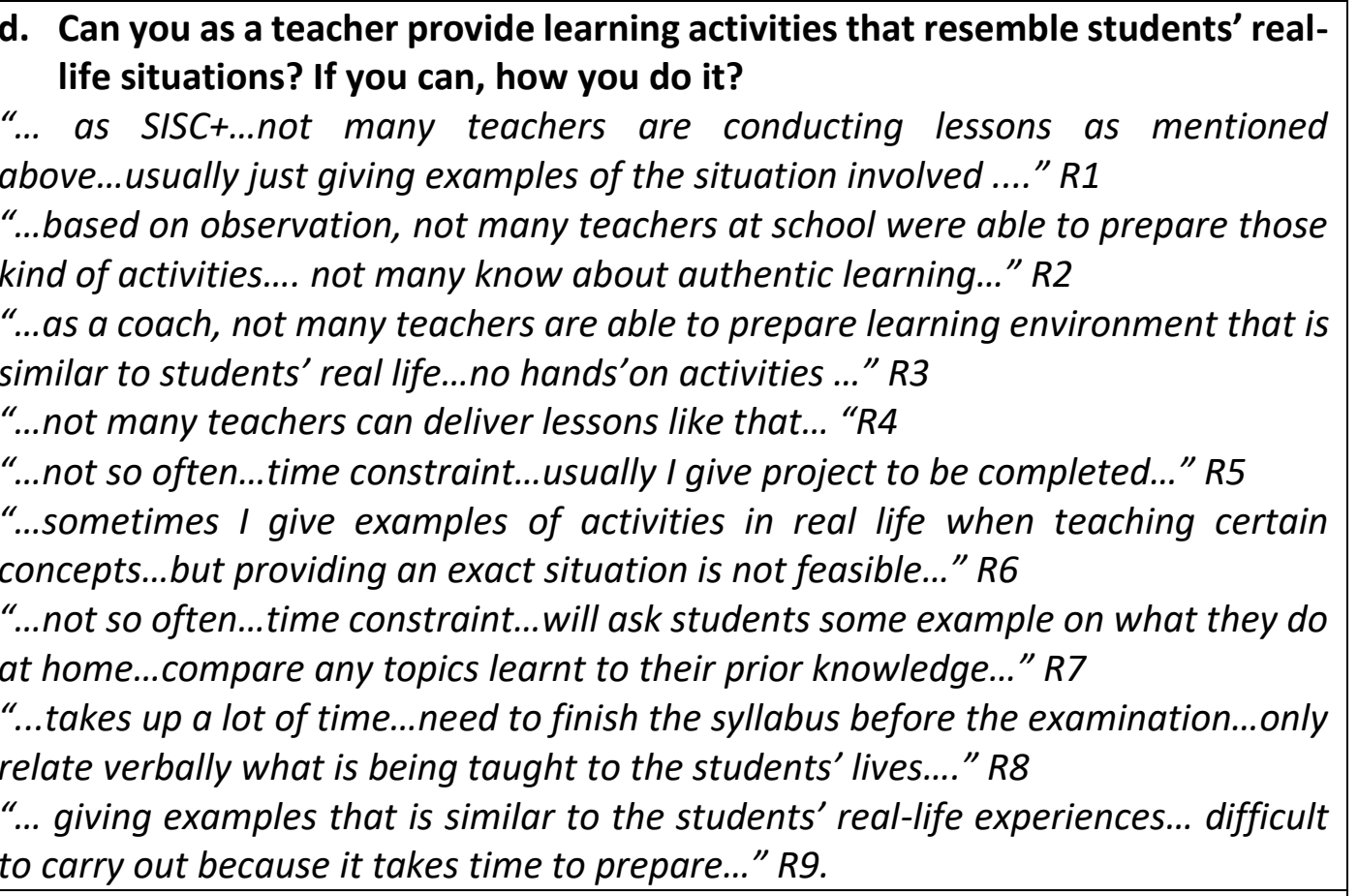 \\
\hline 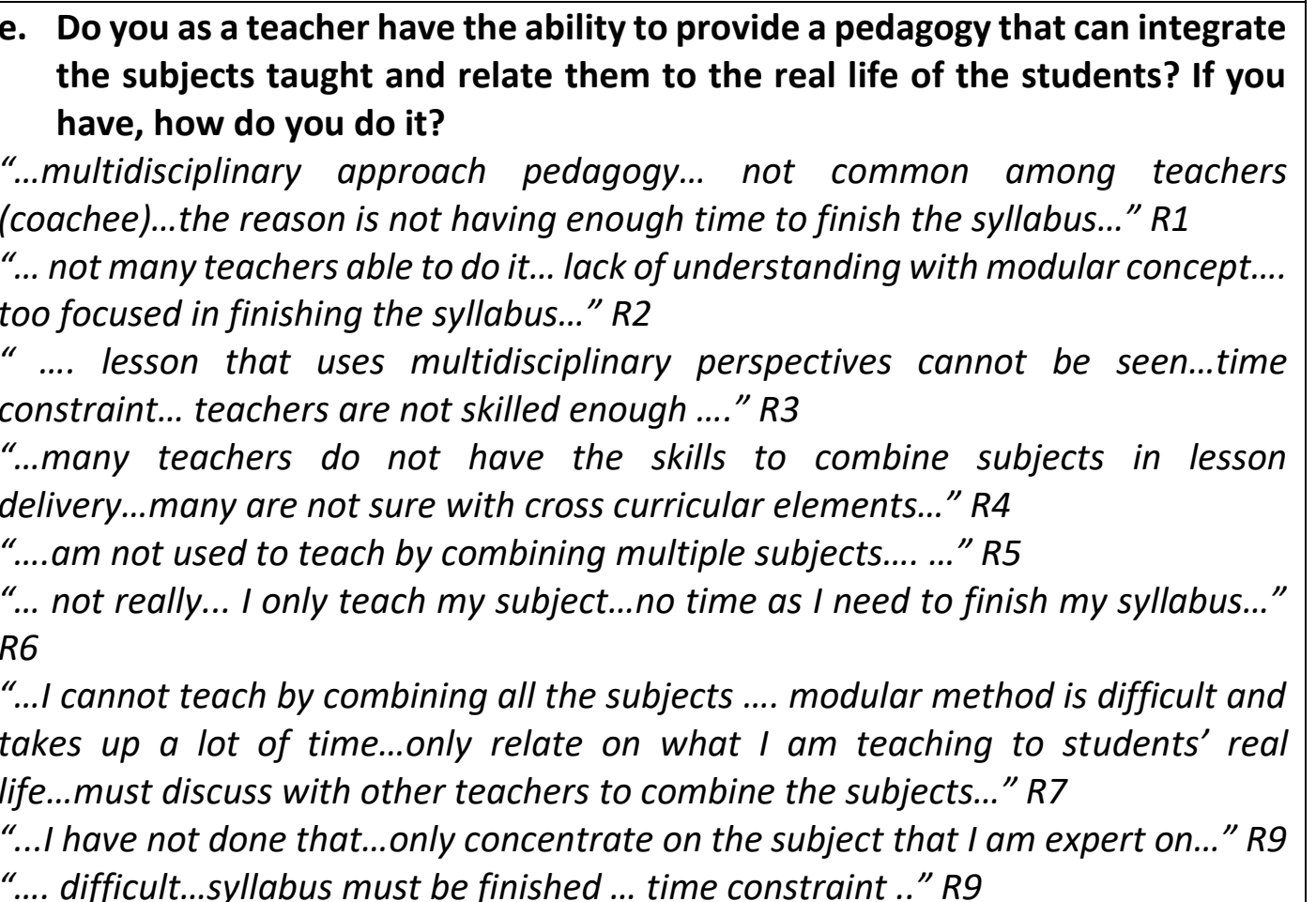 \\
\hline
\end{tabular}


f. Can you provide a learning environment with access to expert skills and opinions? How do you execute that?

"...during coaching and mentoring session, never seen.... mostly co-academic programmes at school will allow access expertise from outside the school environment...." $R 1$

".... not all teachers in Manjung skillful enough to conduct networking with experts from other fields...." R2

"... most teachers are not able to involve experts from other fields in the pedagogy....only through special programme carried out at schools..eg ...Fire brigade or Police...." R3

"...sharing of ideas only happen when there are programmes..." $R 4$

"... difficult to carry out...need permission from the administrators...usually I just show videos about the topics related..." $R 5$

"...very difficult to contact those experts...need permission...must be aligned to the lesson...time constraint..." R6

".... not really...must write invitation letter...permission from the school admin...long and tedious process..." $R 7$

"...difficult to carry out...need permission from school...usually during school programmes, experts will be invited..." 88

"...only during special programmes...need permission...many SOP must be followed..." R9.

g. In your opinion, can students apply the knowledge and skills learned in school session to their real lives? R1

".....it is possible...if the lesson involves activities that is similar to the learners' experiences in life...." $R 2$

"...if given chance...can... but must be guided....." R3

"...not very significant .... Because teachers will be focused on finishing the syllabus... mostly focused for examination.... during that time, not many problemsolving skills will be taught..." R4

"..... when teaching doesn't involve $21^{\text {st }}$ century skills, .... chances of them to apply knowledge in the real life is not much..." R5

".... difficult.... subject only taught based on facts...no hands-on experiences.... not able to understand the concepts.... only memorizing..." R6

"...if I continue teaching using textbook only...it is rather useless...many things taught not relevant to the students' life.... knowledge and skill can be applied if taught that way...." R7

".... only some knowledge taught can be applied in the students' real life... but not all... only facts are delivered for them to sit for examinations..." $R 8$

"...if traditional pedagogy is followed, difficult for the students to apply it .... but if the activities are similar to the students' real life, then it won't be much problem..." R9

h. Can you as a teacher, design a learning strategy that enables students to explore issues from different perspectives?

".... as a coach...not many teachers are able to do it.... Even when the teacher claims that .... it is $21^{\text {st }}$ century learning skills...but inputs are based on the teachers' perspectives....." $R 1$ 


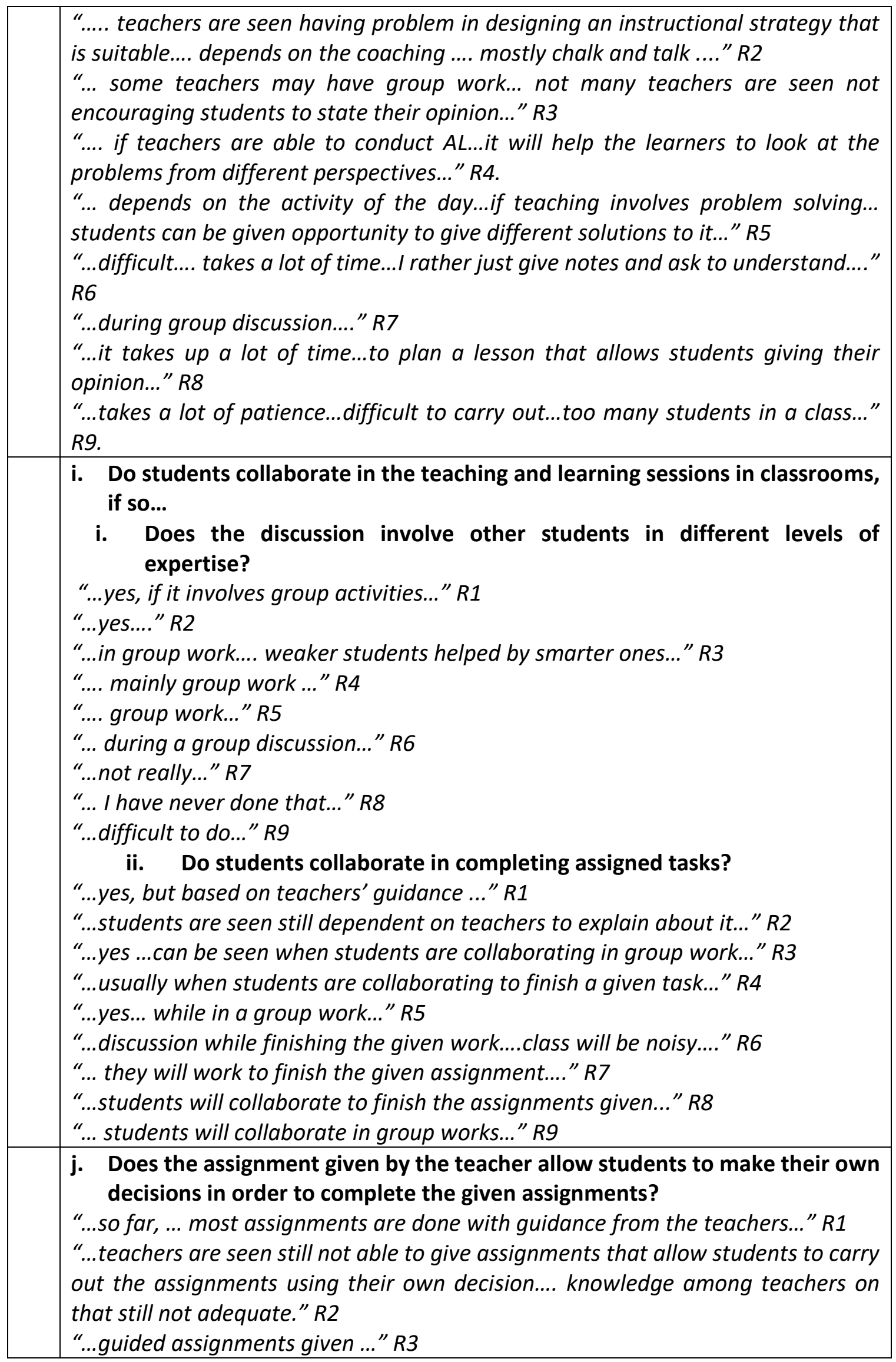




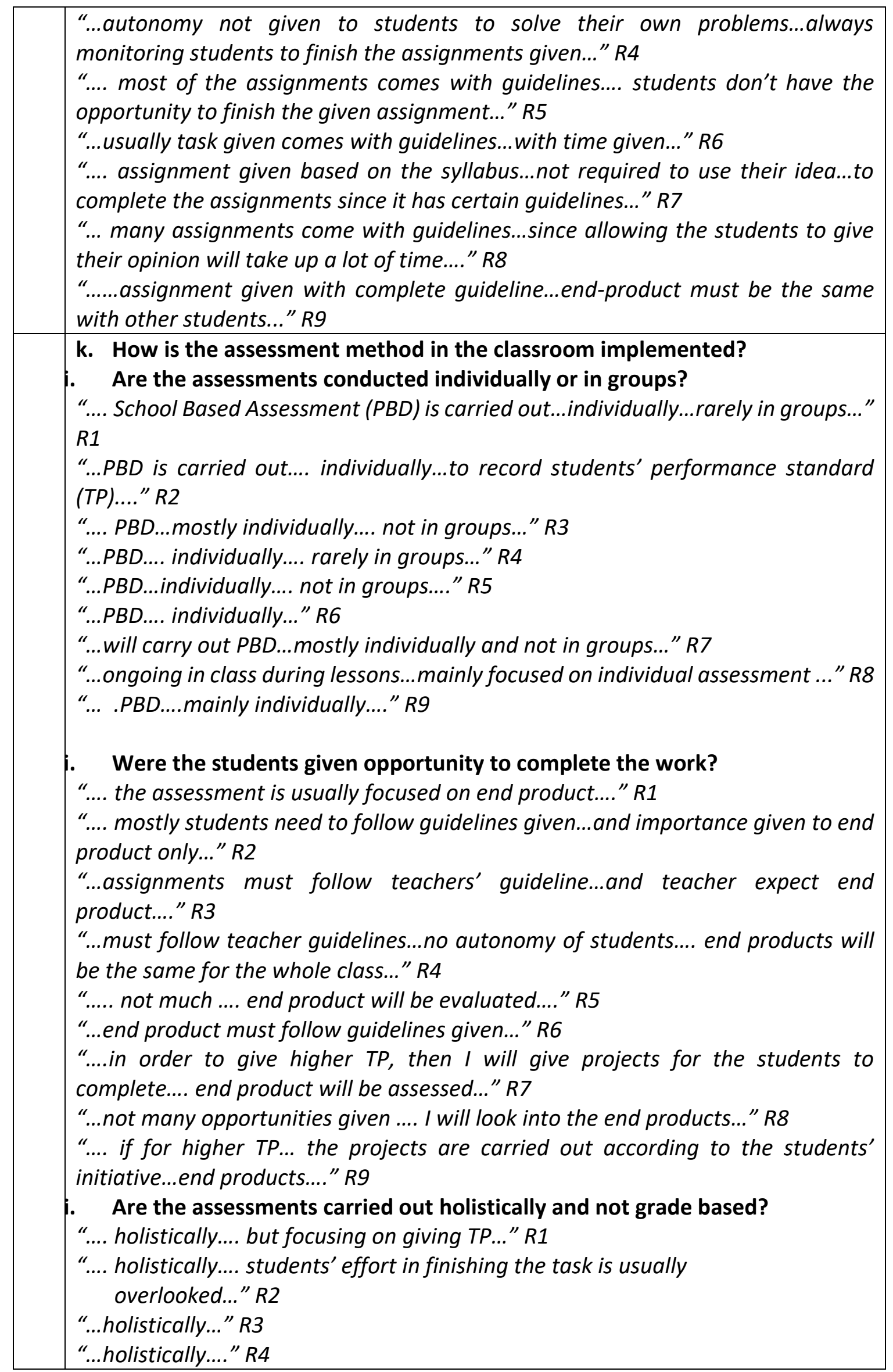




\begin{tabular}{|c|}
\hline $\begin{array}{l}\text { “...holistically...but mostly focused on end product..." } R 5 \\
\text { “...holistically...” } R 6 \\
\text { “...usually given holistically..." } R 7 \\
\text { “...usually given holistically...." } R 8 \\
\text { “...holistically..." } R 9\end{array}$ \\
\hline 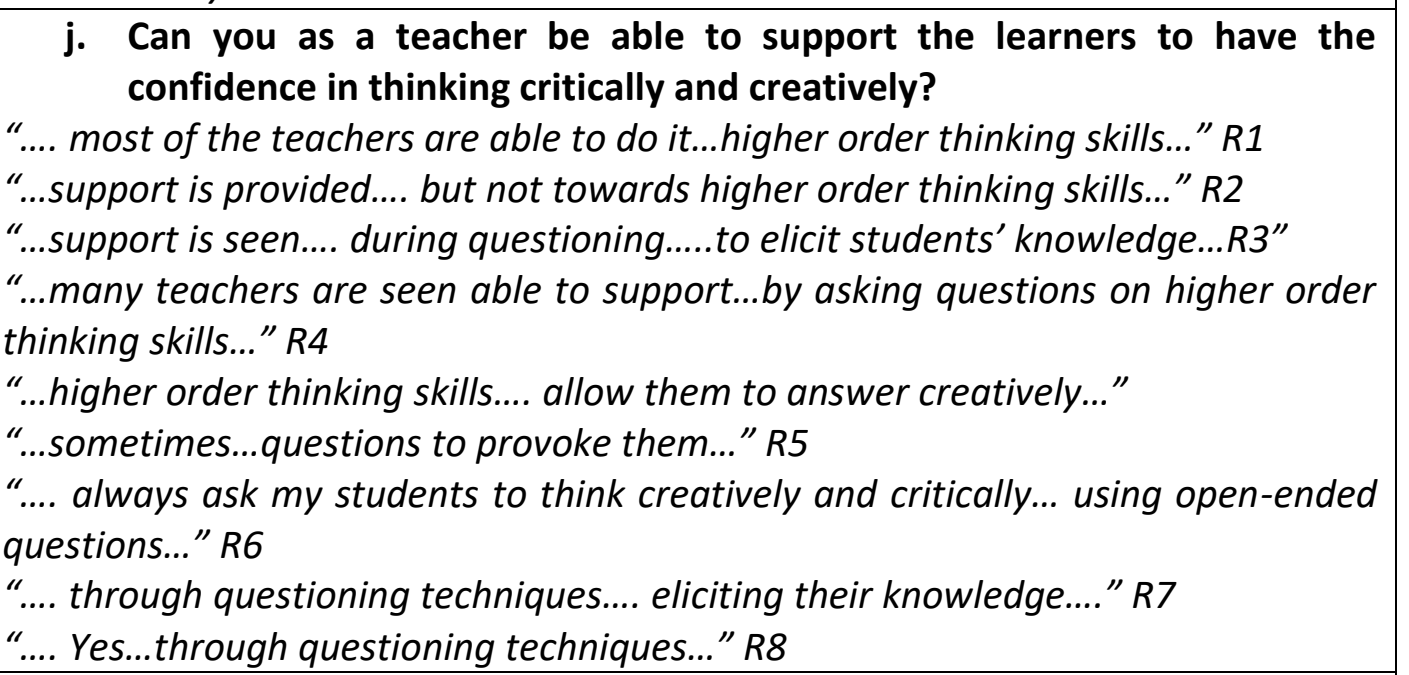 \\
\hline $\begin{array}{l}\text { k. In your opinion, can authentic learning approach meet the learning needs } \\
\text { of students? } \\
\text { "...AL able to fulfill the needs of mastering } 21^{\text {st }} \text { skills..." } R 1 \\
\text { "...As a coach...AL can help...but teachers are still focused in finishing the } \\
\text { syllabus...." } R 2 \\
\text { "...AL can help students to become more functional..." } R 3 \\
\text { "...AL is capable to fulfill the students' needs...to function in the future..." } R 4 \\
\text { "...if taught well....it can help...teachers must have the right knowledge and skills..." } \\
R 5 \\
\text { "...AL can help in fostering } 21^{\text {st }} \text { century skills...closer to their daily lives..." } R 6 \\
\text { "... if carried out well....it can help in instilling } 21^{\text {st }} \text { century skills..." } R 7 \\
\text { "...yes.... if done correctly..." R8 } \\
\text { "....it can help in instilling } 21^{\text {st }} \text { century skills..." } R 9\end{array}$ \\
\hline 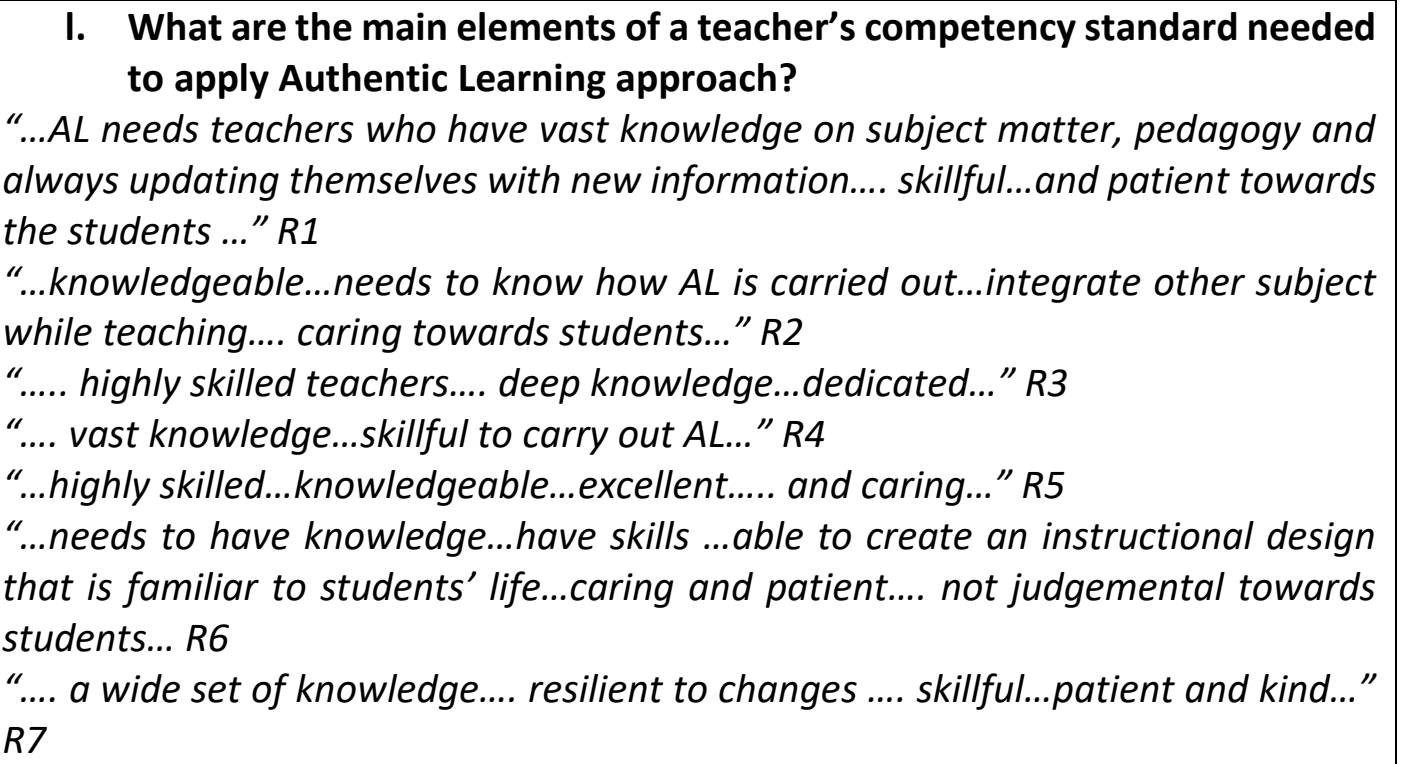 \\
\hline
\end{tabular}




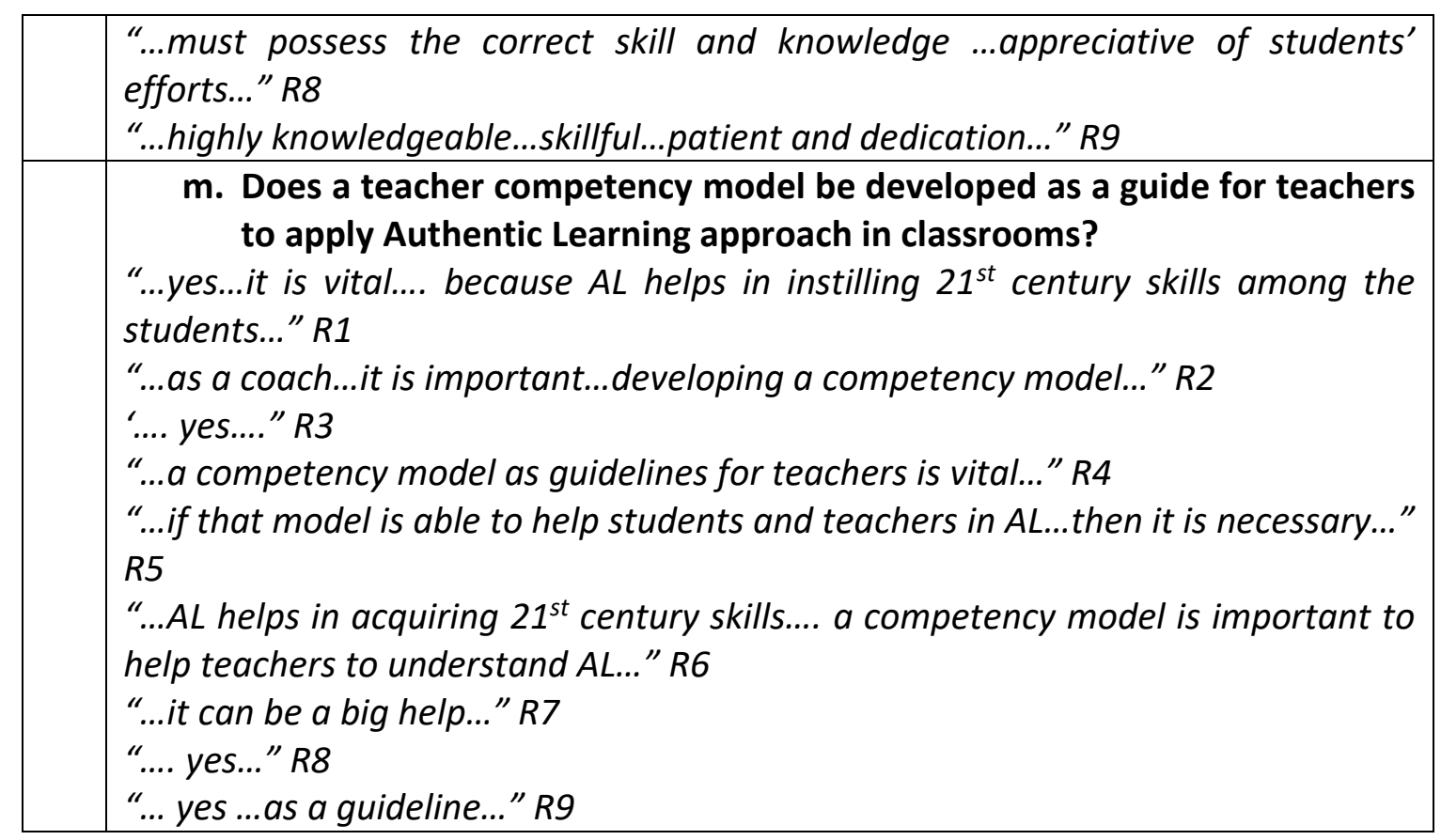

